\title{
My music, my voice: Musicality, culture and childhood in Vhavenda communities
}

\author{
Andrea Emberly \\ York University, Canada \\ Lusani Antoinette Davhula \\ University of Pretoria, South Africa
}

\section{Corresponding author:}

Andrea Emberly, Children's Studies, York University, 262 Vanier College, 4700 Keele St., Toronto, ON M3J 1P3, Canada.

Email: aemberly@yorku.ca

\section{Abstract}

The notion of children's "voices" is a construct used to frame the lack of power and agency that young people yield in their lives. However, representing children as "voiceless" overlooks how they employ tools, such as music, to voice their agency in dynamic, articulate, and meaningful ways. This collaborative article examines how children and young people in Vhavenda communities in South Africa utilize music to straddle their realities between tradition and change. Through this exploration, we will demonstrate how children and young people shape, embody, and challenge the lived and contemporary notions of what it means to be Vhavenda.

\section{Keywords}

Children's voices, musical arts practices, South Africa, Vhavenda, youth

\section{Introduction}

In the field of Childhood Studies, children's "voice" or "voices" has been a dominant discourse, often standing as a challenge to provide a space where children's voices may be heard. These appeals aim to overcome the metaphoric silencing, dismissal, and suppression of children's agency (see, for example, Barron, 2014; Bucknall, 2012; Grover, 2004; Hallett and Prout, 2003; Hill, 2006; Hohti and Karlsson, 2014; McTavish et al., 2012; Phillips, 1995; Ridge, 2005; Schnoor, 2012). The overuse of the rhetoric surrounding children's 
voices has been critiqued, with scholars arguing that the presentation of children's "voices" can become tokenistic and void of context, and emphasizes the idea that "children have 'voices', but only adults have opinions" (interview with Ennew in Carmel and Greene, 2014: 81). ${ }^{1}$ James (2007) argues "the very conceptualization of, variously, 'the voices of children' or 'children's voices' risks glossing over the diversity of children's own lives and experiences" (p. 262). This conceptualization can therefore often exclude "children's active (and not so active) role in social and cultural reproduction" (Spyrou, 2011: 160).

Regarding children as "voiceless" further perpetuates stereotypical power imbalances where those with power must provide allowed or allotted space for listening. This lack of regard for what is already voiced perpetuates silencing, given that children and young people do indeed voice their views, often loudly, through creative and expressive means. Music is one such avenue that children and young people employ to voice, to connect, and to shape their own distinct and diverse cultures of childhood. This expressive space has often been overlooked in the dominant adult discourse that positions children as receptacles and receivers of knowledge, diminishing recognition of the agency they deploy as creators and propagators of their dynamic musical traditions. Children and young people often engage with musical arts' practices to inculcate and sustain their voices within a particular context, whether it is culture, community, place, or space.

In rural Vhavenda ${ }^{2}$ communities in Limpopo province, South Africa, children and young people utilize music, dance, and song to engage with what it means to be Vhavenda in a rapidly shifting local, national, and global landscape. Children and young people have distinct and valuable insights into how and why they cultivate and foster Vhavenda musical arts practices ${ }^{3}$ within a multicultural and global South Africa. This article presents a collaborative dialogue and reflection on how and why musical arts are voiced and fostered by children and young people in Vhavenda communities between Emberly, an ethnomusicologist, and Davhula, a Vhavenda young person. While the theoretical framework is primarily provided by Emberly, it should be recognized that the analysis is informed by ongoing discussions between both authors and reflects the complexities of intercultural and intergenerational collaborative authorship.

The conversations between Emberly and Davhula that frame this article consider how young people voice their culture in dynamic, articulate, and meaningful ways in order to shape, embody, and challenge the lived and contemporary notions of what it means to be a Vhavenda young person today. Davhula is a 20 -year-old student at the University of Pretoria who has grown up in Tshakhuma, a rural Vhavenda village. Emberly and Davhula have known each other since 2004, and between 2014 and 2016 they have engaged in an ongoing dialogue about the complex realities of young people's lives in current South Africa and how music shapes a relationship to culture in the Vhavenda context. Davhula is proficient in what people term "traditional Vhavenda music" and can sing, drum, and dance but she does not describe herself as a musician. Unlike her parents and grandparents, Davhula primarily learned traditional Vhavenda music in the school classroom, although traditions were also fostered at home where singing and dancing are highly valued as cultural capital. ${ }^{4}$ The questions that we have discussed at length focus on how and why Davhula values music as an important and central part of her life, how this applies to her peers, and the intersections it has with the notion of audibly voicing culture within multicultural and global landscapes. As young people who grow up in 
rural Vhavenda communities integrate into the multicultural and urban centers of South Africa, they face sociocultural, racial, and class politics that challenge their individual, cultural, and national identities. As such, this dialogue has become more resonant with understanding how and why young people view musical engagement as a space for cultural maintenance and expression and how music is "cultural resource for both cognitive and socioemotional development" (Serpell and Marfo, 2014: 104).

The authors' discussion aims to move beyond stereotypical images of children in Africa by presenting the lived experiences of a young person who recognizes the role of music in fostering both tradition and change. As Jackson (1996) argues, the individual story serves to "remind us that meaning takes shape in the transitory, multiplex, and phenomenal forms of particular lives" (p. 23). This resonates with the intersubjective meanings attributed to traditional music in the Vhavenda context, and in particular, by the ways in which young people ascribe meaning to sustaining culture through musical engagement. Davhula's narrative of growing up Vhavenda voices her experience of culture amidst the rapidly shifting social, cultural, and economic landscapes of South Africa. Her views, while individual, are indicative of a collective consciousness articulated by many Vhavenda adults and young people today ${ }^{5}$ - that tradition is being overridden by modernization and globalization and Vhavenda young people are losing their musical traditions, thus losing their culture because the two are intrinsically linked. However, rather than viewing the loss of tradition in a deficit model, this article examines how the adaptive processes of traditional Vhavenda musical arts learned today in school classrooms rather than community contexts, drives the articulation of Vhavenda culture in the South African context. The individual ideas expressed here, while subjective, do represent the experiences of many Vhavenda young people who face pervasive assumptions about being Vhavenda that are tightly wound in race, culture, class, and power politics of current-day South Africa.

Rather than giving, or providing, a space for children's voices, this article contextualizes individual experience as an important space of articulation given that it has been identified that there is a "struggle by the elderly to transmit older cultural forms to young people" (Kruger, 2014: 17). Kruger (2014) notes that that there is a current "sense of disorientation" in Vhavenda communities due to the loss of traditional performance genres and he argues that song/storytelling (ngano) is "instrumental to the autonomous negotiation of identities in a globalising world" (p. 14). This loss is also described by Davhula, who maintains that, although young people do perform musical arts at school, it is rare to find youth listening to traditional music. This disruption of knowledge flow creates tension for young Vhavenda people and connects to a broader cross-cultural concern in the field of applied ethnomusicology that underscores how deficit models often overlook the adaptive and transformative frameworks embedded within musical processes. As such, performance of traditional Vhavenda music is viewed locally as sustaining socio-cultural wellbeing through the adaption and strengthening of musical systems within pressures to conform to national and global identities (Titon, 2015).

\section{Being Vhavenda in South Africa}

Within the 11 official languages of South Africa, Vhavenda speakers make up about only $2.4 \%$ of the population of the country, making it one of the least spoken languages in 
South Africa. Vhavenda communities are primarily rural, situated in the most northerly Vhembe district of Limpopo province. ${ }^{6}$ Distinguishing oneself culturally amidst the multicultural, or rainbow nation, of South Africa is an integral part of growing up. This is particularly resonant for young Vhavenda people who study in urban centers where, despite the diversity of their life experiences, they are often essentialized down to a singular cultural identity.

When discussing how one distinguishes oneself as Vhavenda when away from home, Davhula explains,

Language is the easiest way to distinguish ourselves. Although we Venda do have a very distinct cultural attire, we are not always dressed like this, it is only for ceremonies or special occasions such as weddings. We are also known for our different types of food.

Even within South Africa, although Vhavenda people live in Limpopo province, most people don't know that. People assume Venda is its own place, people always refer to it as Venda, you come from Venda. The expression makes it seem like it is a separate province.

This leads Davhula to consider stereotypes and what people think about being Vhavenda:

I admire that in my culture, wherever I go, people respect Venda people. We are people of morals, we cook good food, we are extremely respectful and very loyal. People also respect us because there is a long-standing stereotype that Venda people use witchcraft, so they respect us because they don't want to mess with us! For example, they would not want to steal from us because they think we might bewitch them!

This is also one of the negative stereotypes, that we are witches. People in South Africa also think that we are too black, they call Venda people pitch black because they think all of us have darker complexions. They also think we are more traditional than other cultures in South Africa because if there are ceremonies we show up wearing our traditional clothes.

Ideas about Vhavenda people also permeate the media landscape where they are often represented as poor, uneducated, unemployed, living only in rural areas governed by the Chiefdom system, and heavily engaged with witchcraft. While terms such as "rainbow children" and "born frees" are often used to describe the next generation of South African children (see, for example, Barbarin and Richter, 2001; Bradbury and Clark, 2012; Bray, 2010; Joubert et al., 2010; Mattes, 2012; Mokoena, 2014), these terms suggest an equality across cultures and equal access to social and political capital.

When determining what these terms might mean for Vhavenda children and young people, Davhula suggests,

The idea of the rainbow nation acknowledges that we are from different cultures but that we need to unite now more than ever. This is especially true with what is happening with hatred between people such as xenophobia. We are also called Mandela's children or Born Frees, meaning children who were born after 1994 and Mandela became president. We are Mandela's children because he helped support everyone when he became president. And we were born free, free from apartheid, free from the racist system. 
As such, being "born free" does not necessarily represent being born in rural South Africa to a minority culture group. The issues that face children and young people in South Africa today are vastly different from the previous generation that saw freedom from apartheid as central to the national identity (see, for example, Cronje et al., 2015; Joubert, 2010; Newman and Lannoy, 2014). Davhula suggests that

Some of the main issues facing young people today are those surrounding lack of knowledge. This is also caused by educational challenges, where access to education is a big issue. This is especially true in terms of access to university; poverty has a big impact on who is able to go to university.

In Venda communities, there is also the issue of language. Children are not necessarily able to communicate well in English, which becomes a disadvantage by the time they want to go to university because it is more difficult and challenging for them.

As noted in the report Born free but still in chains (Cronje et al., 2015), over half of the population of South Africa is made up of children, teenagers, and young adults, and “'born frees' are seen by some as a 'post-racial generation' less likely to be governed by racial thinking than their parents were" with the primary areas of issue being unemployment, education, family life, and crime (p. 1). In the \#FeesMustFall campaign of 2015, South African university students protested the rise of tuition, shining light on issues such as access to education, completion rates ${ }^{7}$ (especially for students from rural, public schools), and class divisions. These social movements demonstrate the voicing of power from young people in South Africa, acknowledging that the rainbow nation does not equally represent all those that make up the rainbow.

Furthermore, Davhula notes that within this rainbow nation, Vhavenda people straddle two worlds:

We (Venda people) tend to view the world from a different perspective that is both modern and cultural.

\section{Being musical in Vhavenda}

In the 1950s, ethnomusicologist John Blacking (1967) introduced the world to the music of Vhavenda children in his seminal text Venda children's songs. The Vhavenda became the site of his ongoing work on the innate potentials for human musicality, as he noted,

Most Venda children are competent musicians: they can sing and dance to traditional melodies, and many can play at least one musical instrument. And yet they have no formal musical training. (Blacking, 1967: 29)

Blacking (1990) was one of the first scholars to link the relationship between children's culture and musicality:

As they grew up they realised that musical experience was an important key to self-knowledge and understanding of the world. The variety of contexts in which children experienced or 
tried to perform music and dance helped them to understand the relationship of artistic skills to social institutions and to value them as means of communication no less important than speech. (p. 77)

The study of children's musical cultures has long been overlooked in the field of ethnomusicology as children's music was often viewed as simplified versions of adult musical structures. However, more recently, children's musical arts practices have been examined as sites of cultural agency with children and young people engaging in musical arts practices for cultural competency as well as musical skill building (see, for example, Campbell, 2010; Campbell and Wiggins, 2013; Green, 2011; Marsh, 2008; Minks, 2002).

In Vhavenda communities, musical arts engagement continues to be a significant site of agency for children and young people and is central to almost every function, celebration, and rite of passage. Although the contexts of musical learning have shifted (Emberly and Davidson, 2011; Emberly and Davhula, 2015), music continues to be an active framework from which creativity, power, and knowledge are fostered. This musical voice of Vhavenda children and young people bridges genre, from traditional to popular, and the intrinsic link between culture, identity, and youth is articulated through musical arts engagement (Emberly, 2013). This active and dynamic musical identity is not bestowed at birth to Vhavenda children but rather carefully and cautiously fostered, as in Figure 1, so it is not lost within the rapidly growing multiculturalism that dominates the landscape.

Using Blacking's work as a historic benchmark, it is clear that children and young people are still engaged with what is considered traditional Vhavenda music (Blacking, 1967). What has noticeably shifted since Blacking's research is that musical competency

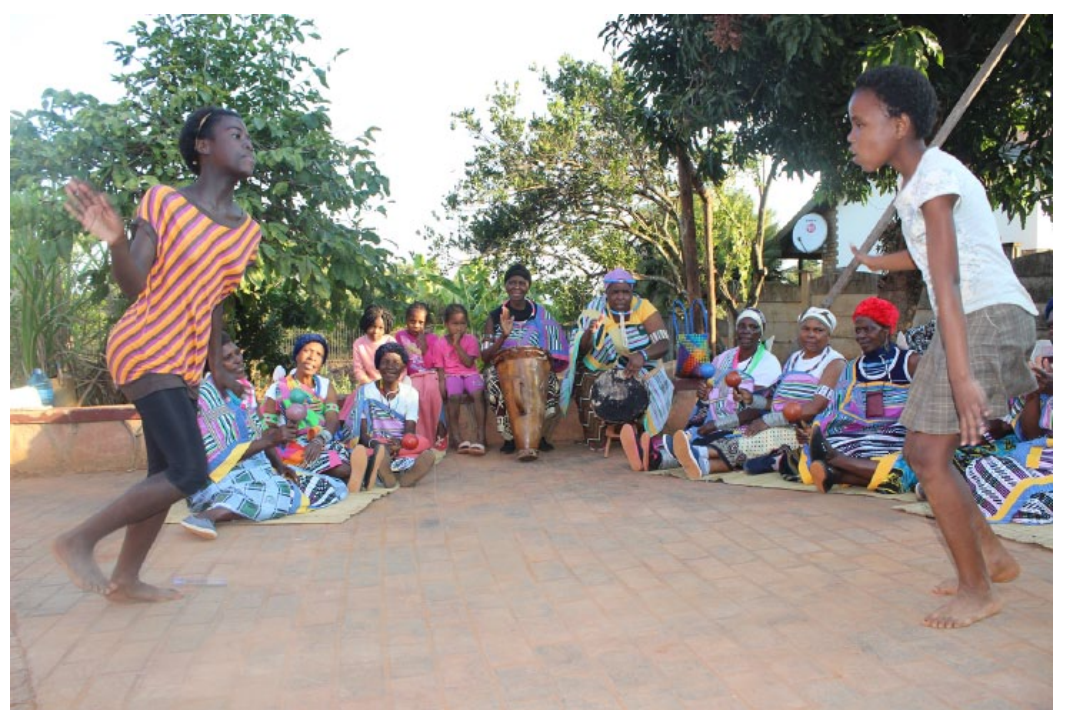

Figure I. Young women dancing malende at home with women from the Malende a Tshakhuma cultural group during a special occasion, Tshakhuma village (I4 June 20I5). 
today is linked to musical multiplicity, that is, how young people in particular apply skill and musical knowledge across genre. This is evidenced by the ways in which young people adapt lyrics in both traditional and contemporary song genres (examples below) and the insistence by young people to maintain and sustain traditional performance genres. As demonstrated in Blacking's findings, Vhavenda youth consider that being musical is intrinsically linked to Venda identity and this holds true today. As Davhula suggests, one must be able to engage in music in order to know where they belong and where they come from in order to know their roots.

Davhula offers that Vhavenda young people engage in music across genre:

We have so many different types of music. Of course there is traditional music, and these are different depending on what culture you come from in South Africa. Pop music, hip-hop, reggae, jazz, kwaito, house music, and gospel, you find these everywhere and find that most young people listen to these types of music. All of these types of music have South African artists, except for pop; pop musicians are really those people from outside the country.

In Venda we have our distinct traditional music, we have local hip-hop (but it is not so recognized outside Venda), gospel music, and local house music.

Music is an important part of people's life in most cultures. In most cases we hear other people's views through the music they listen to. Music can express people's personalities and dreams. It can show who brings history into the world and who can change the world. Music can be used to cultivate, educate, inspire, and unify your life as well as others'.

Music affects a generation in many ways. Our slang language comes from music. Our fashion can come from something an artist wears. I also believe that music can affect a generation in positive and negative ways. Many artists sing about what they believe in. Singing in what they believe in is the most influential thing artists can do. It is important not to lose the music of our culture and also important to be a part of South Africa and the world. Music is one way we can do this.

What has been highlighted through the present discussion about learning music is that there is an underlying importance in learning Vhavenda cultural values and traditions that is articulated through musical arts engagement. It is clear that music contributes both to understanding Vhavenda culture and to creating pathways outside and among local, national, and international communities of young people.

\section{Learning traditional music}

As tradition is an evolving and changing construct, understanding where and how children and young people learn music is important. Given that the functionality of musical arts practices has changed drastically since Blacking's research, and given that musicality is imparted to children early in their lives, it becomes clear that children and young people are at the epicenter of preserving and fostering the musical processes and frameworks that will lead to the sustainment of musical arts practices. Davhula suggests that both children and adults must be engaged in order to keep culture strong (Figure 2): 
It is very important to preserve our culture and we do this through traditional music. We do this through preserving traditional songs. Many of these songs are educational; we cannot stop singing them because we will lose our Vhavenda education. We learn language through song, we learn respect, we learn so much more than just music.

Traditional music is evolving and being altered because of current situations. In the olden days children learned music during ceremonies, like the domba initiation schools, they had activities and each activity had its own set of songs and dances. The songs they sang also had more purpose, for example girls would go and get water at the river and there would be a song for that, the would have a song for grinding or for the different types of work they had to do.

Today children learn Venda music in crèche and primary school. Sometimes if there are grandmothers at home they might still learn some folksongs from them, but most of the learning happens at school. The music is then adapted because children are not treated the same way they used to be, there are not so many expectations on the kinds of work they have to do. So many of the old songs are about labour, about fetching firewood or water, but now the songs must be adapted because there is running water in the house, there is electricity, so music adapts to children's new lives.

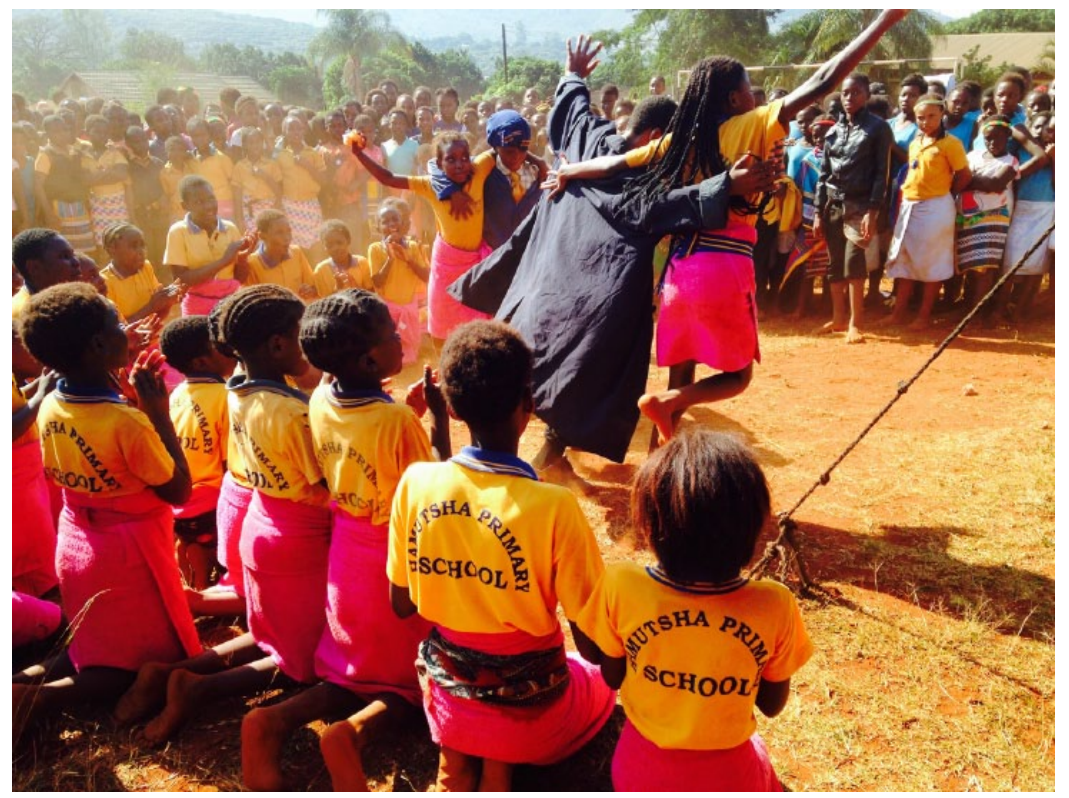

Figure 2. Children from Hamutsha primary school in the Dzondo circuit, Vhembe, Limpopo compete in a Vhavenda cultural competition (28 May 20I5).

For example, my 6-year-old niece was singing a song she learned in kindergarten (Figure 3). When my aunt listened to her singing, she was surprised that some of the lyrics of this old song had been changed. Words like "jersey" were substituted for old words like "zwikapa" (a type of traditional shawl). So, the children were learning the melody and style of Venda songs but with updated words and language: 


\title{
Hovhila ho wa (It is well fermented)
}

\author{
Hovhila ho wa \\ It has fermented well, it is well matured (in reference to milk, it turns sour)
}

\section{Ho tou bebebe}

When you swallow it, you will say it comes down so well, it satisfies

\section{Vhatukana jersey}

Boys wear jackets

\section{Vhakegulu Misisi}

Grandmothers wear the traditional clothes (misisi = specific type of Venda traditional clothing)

\section{Vhakalaha Madzhasi}

Grandfathers wear overcoats

Vhakegulu minwendwa

Grandmothers wear salimpos (traditional outfits)

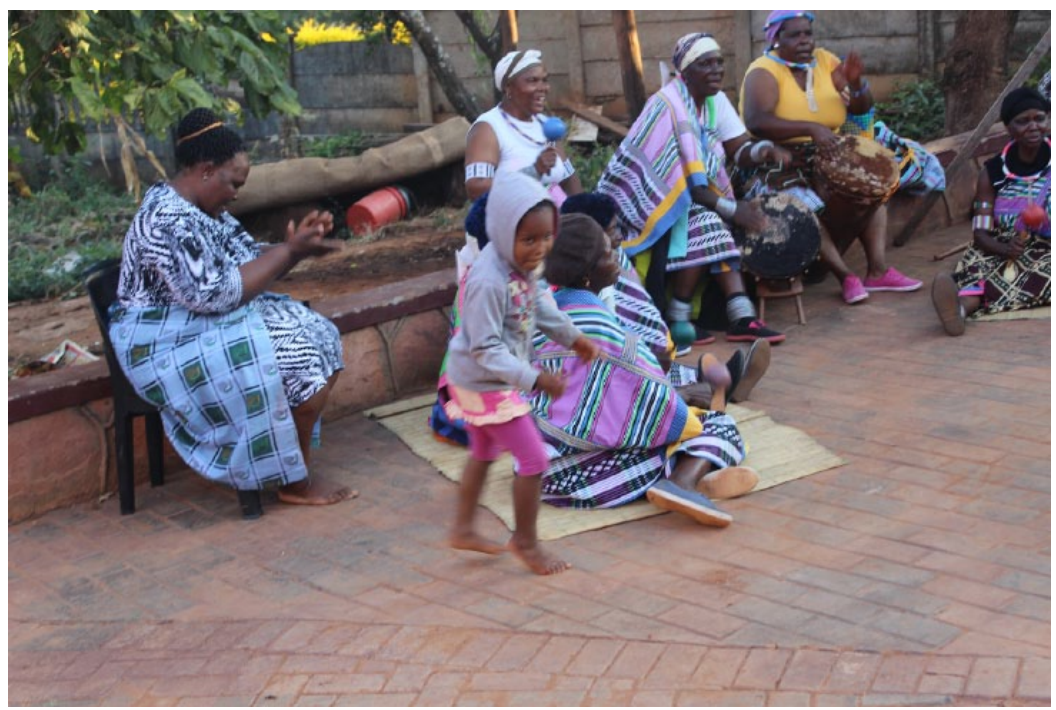

Figure 3. Davhula's niece singing at home in Tshakhuma village during a special occasion with women from the Malende a Tshakhuma cultural group (I5 June 20I5).

Adaptation of song lyrics is a key component of traditional Vhavenda music, singers discussing subjects such as politics, disputes, and current events through the adaptation of lyrics to a traditional melody. In the case of Hovhila ho wa, it is likely that a 
schoolteacher adapted the words as many traditional songs get "updated" in the school curriculum. Lyrics that address health issues such as cholera and HIV are adapted to old song melodies and young people learn that song melody and subtle language can be used to discuss pressing issues. Adults are not the only adapters of songs; young girls in particular become adept at this skill while singing skip rope and handclapping songs. The following song was created on the playground, an old melody adapted to share the news of the death of Mandela and to connect to the national sense of grief and loss:

\author{
Nda doba vhurifhi \\ I picked up a letter \\ Nda vhuisa kiliniki \\ I took it to the clinic
}

Vha mbudza zwa uri, Mandela o louva

They told me that Mandela passed on

\title{
Nda lila ndo lila \\ I cried and I cried
}

Other handclapping songs (transmitted between children) situate Vhavenda in the global landscape. Emberly has recorded this song in other areas in South Africa but without the verse on Venda; other versions of the song include Ireland and Congo, but no other verse depicting a South African cultural group has been recorded (Emberly, 2009). This demonstrates how Venda children view themselves as culturally independent from South Africa, asking Mandela to come and see what happens in Venda:

\footnotetext{
Mandela went to China

To see what happens in China

It's really nice in China

But what about in China

Mandela went to India

To see what happens in India

It's really nice in India

But what about in India

Mandela went to Venda ${ }^{8}$

To see what happens in Venda

It's really nice in Venda

But what about in Venda
}

Other factors, such as technology and cultural changes also impact musical adaptation. Davhula suggests,

Technology has also brought media into the house. Now we listen to other music, we spend time listening to that music, we have less time to listen to Venda traditional songs, to sit with 
friends and sing songs. Now we don't sing traditional songs as a family so much, so when we do it is very important and I like to record it so I can take it with me and listen while I am away from my family and away from my culture, it is a precious moment.

In the olden days, families used to gather around a prepared burning fire, this would happen normally after supper. They would sing traditional songs since it was considered unhealthy to go to bed immediately after eating. Normally this would be done with grannies and their grandchildren. One example is a song taught to me by my grandmother called "Thathatha," which is just a repetitive rhythmic sound. Like most Venda songs, this song has a moral, and the moral is that you must know who to trust and who not to trust.

\section{Chorus:}

\section{Thathatha thanga dzi a swa}

When they burn, if they are not being attended, they will pop and burn

Like most Venda songs the words have hidden meanings that get told to you through the folk stories that the old people tell when you are learning the songs.

Music in Venda is taught and transmitted from one person to another orally. When we learn music, even in the classroom, we still learn this way. And we also still learn from our elders in some ways. We still learn some of the old songs, like the song my grandmother taught to me, because we don't want it to vanish, we want to be able to know what they used to do in the old days, so we can get a picture of what used to happen.

As noted earlier by Kruger, there has been an erosion of the transmission of knowledge through song and storytelling between elders and young people. However, finding new pathways of transmission is viewed as important, not only for the sake of cultural heritage but also to retain fundamental cultural knowledge that is embedded within musical practices. This knowledge is often buried within language so that the performer must be able to not only sing the song but also interpret the knowledge. Like in the song from Davhula's grandmother, young people must have musical and cultural/language skills to interpret meaning from lyrics, such as

\section{Call: Ndi tshi bika vhuswa e sa li}

When I cook porridge, and he does not eat

Response: Nde o lamba

I say he has refused

Literal translation does little to unearth the meaning of the song, but cultural knowledge is imperative to interpret the actual meaning of that song that suggests that one who does not eat porridge is one you must be cautious of. Thus, music is one way for Vhavenda youth to understand and sustain culture and to make sense of difference within the rainbow nation, to grapple with an understanding of what diversity means in current South Africa. Retaining and sustaining traditional music practices also enables Davhula to engage with cultural practice and values in order to connect the past with the future: 
I must say that it is something that is generally unspoken ... today's youth see that the value of our culture is gradually decreasing and most of our tradition is being lost day by day ... some are even ashamed to admit to the fact that they fall under a certain culture when they are with their peers. We are more likely to feel more connected to our peers at home (Venda peers) than those at varsity ... It is easier to make friends related to you in either where you come from, what you speak, eat or do.

However, Davhula notes that even though the challenges are great,

Traditional song must be preserved or revised or taught to the current generation, before they become extinct. If this happens upcoming generations will know nothing about their roots, which are what make us special and unique.

\section{Musical tradition and change}

Being musical in Vhavenda communities is a distinct priority, for both children and adults. Although there are genres of traditional music that have suffered (Emberly and Davhula, 2014), it has also been demonstrated that young people are dedicated to the maintenance of traditional musical arts practices. This is not only to gain cultural competencies but also because music is embedded with cultural learning that centers young people within the Vhavenda cultural context amidst the multicultural rainbow nation (Figure 4). As Davhula articulates,

Music has always been important for Venda culture. If there was no music in primary schools, it would be the birth of death in our traditions, because music plays an important role in who you might become. Music can have a major influence on your behavior and your life.

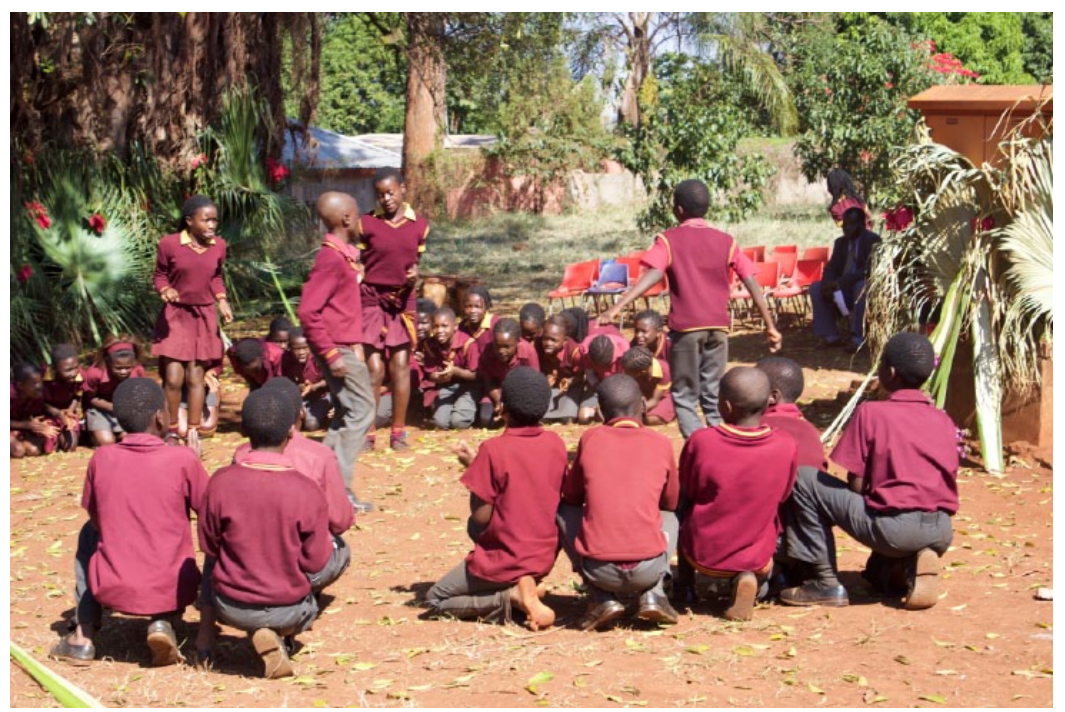

Figure 4. Learners at Raluthaga Senior Primary School, Tshakhuma, practice Tshifasi (June 20I5). 
If we lose traditional music, it means traditional activities, tradition itself and traditional ways of doing things are going to disappear, because I believe that music holds culture. And we as young people must hold this culture so it does not disappear.

But tradition also means adapting and evolving, that it is not static because people are changing. It is important as young children grow up, they will learn about things of a new generation, they don't know about previous generations, so traditional songs might not make sense to them. So tradition needs to accommodate children's experiences today in order for the music to make sense. This type of change is a way to engage children, keeping things static makes kids less interested, but by musical traditions evolving it keeps them engaged and wanting to continue the tradition.

\section{Building on musical skills}

The adoption and adaptation of musical styles in youth cultures, especially in terms of popular culture, have been documented and analyzed as a site of identity formation around the world (see, for example, Bennett, 2004; Huq, 2006). In Vhavenda communities, young people utilize their learned musical skills as a means to create and voice cultural capital in a multicultural musical landscape. VenRap has become one prominent mode of musicality that transgresses the idea of traditionalism while integrating Venda cultural ideas and ideals into lyrics. There are also musical parallels between hip-hop and Vhavenda traditional musical genres that privilege the improvisation of lyrics to address current issues, much like a traditional malende 9 song might be used to speak out about a certain political situation, hip-hop is often used in a similar way as Davhula notes,

Today Venda hip-hop is also an important way to use music as a tool for education. Venda hiphop talks about discipline, about not going to school and what might happen to you. It is a kind of education, about how we use technology too much. It also speaks a lot about self-respect, in this way it is also reflective of Venda culture.

There is growing advancement in the world - we are the changing generation, we are fitting into new things, so they sing about this. In this way we can see there are similar ideas in both traditional music and hip-hop about certain topics. Really it is the same as the old days, people sang about what was important to them at the time, so you might have words that are more meaningful to the generation today.

An example is a recently composed VenRap song (2015) about xenophobia, a topic heavy on the minds of young people as it intersects with current issues such as unemployment, poverty, and ideologies of rainbow nationhood. The song, Show Love by aspiring musician Davhunesh (20-year-old living in Tshakhuma village), demonstrates how Vhavenda musicality links tradition and change, with musical competencies learned during childhood being applied to creative and emerging avenues for sharing stories and ideas through music. A verse and chorus from the song are as follows:

Why do we always have to hurt each other feelings

Cause everyday of your life you hating and teasing

Lets us love show the young ones how to love

Lets hold our hand and look up in the sky lets see a dove 


\title{
Chorus:
}

\author{
Let us love another \\ Let us care for each other \\ Let us stay together and forever \\ Let's be together \\ Let's never hate \\ Never hate each other
}

\section{Conclusion}

Wherever I go, I need to adapt, to fit in. But it doesn't change who I am as a cultural person. But it can mean that we tend to ignore our culture and this is something we need to be mindful of. Music is an important part of my culture. We know that music has a profound effect on your mind, spirit and behavior. When we teach children our music, our culture, they will grow up to be young independent leaders of our culture. Like they say "it takes a community to raise a child" and the more people who perform Vhavenda music, the more likely the listeners will attach to what is being emphasized. This is because music has an impact on everyone, on children, on young people and literally everyone in our culture.

The complex realities of the lives of children and young people in Vhavenda communities are shaped by processes of change and adaptation. This conversation has elucidated the nuanced views that young people in Vhavenda communities have about straddling tradition and change, and of their active agency in propelling their communities into the future. The discourse of Afro-pessimism that shapes global representations of childhood across the African continent contributes to the silencing of the modes and modalities that young people use to make their voices heard. There are parallels to be drawn in the field of Childhood Studies, which has too often relied on creating spaces for children's voices, rather than recognizing that perpetuating mythologies about a lack of voice detracts from the vocal power entrenched in the musical cultures of children and young people. The power that is drawn from musical engagement is evidenced through the articulation of how closely music is tied to cultural identity in Vhavenda contexts. The power of the musical voice thus challenges negative global discourse and representations of African children and young people as voiceless.

Musical arts engagement in Vhavenda communities of children and young people continues to create what Blacking (1967) called an "audible badge of identity" (p. 29). The tension between tradition and change is carefully fostered within this musical identity when young people recognize the importance of sustaining traditions while simultaneously adapting traditions in order to integrate layers of identity into the multicultural rainbow of South Africa. Music is a means of power in the lives of children and young people and, in the case of Vhavenda, serves as an audible emblem of culture. Vhavenda children and young people use music today as a means to gain cultural competencies, shifting its functionality from its historical context. These newly created spaces underscore the proactive engagement that is taken by old (continuing to teach songs and bringing music into the classroom) and young generations (adapting songs and bringing messages into different genres). Although children are often positioned as voiceless, this 
collaborative discussion has privileged how Vhavenda children and young people are at the forefront of utilizing music as a means to assert power in order to maintain and sustain cultural practice within their communities.

\section{Funding}

The author(s) disclosed receipt of the following financial support for the research, authorship, and/ or publication of this article: This research was supported by the Social Sciences and Humanities Research Council of Canada.

\section{Notes}

1. See also I'anson (2013), Jackson and Mazzei (2009), James (2007), Komulainen (2007), Lewis (2010), Lundy (2007), and Spyrou (2011).

2. The term Vhavenda is the term that denotes people from the Venda culture (muvenda $=$ single). The word Venda is also often used to describe a person.

3. The term musical arts practices is used to denote the integration of music, song, dance, and drama (Herbst et al., 2003).

4. See Emberly and Davidson (2011) for further discussion of this shift of learning from the community to the classroom.

5. The authors acknowledge that there is a multiplicity of experiences within communities discussed; however, the observations and views presented are common and pervasive among many young people in Vhavenda communities.

6. This area was semi-independent during apartheid and known as Vendaland.

7. http://www.dhet.gov.za/ (accessed 23 November 2015). Current statistics put completion rates at $15 \%$.

8. Each verse of this song also has a hand gesture to represent the culture, of interest was the gesture used by the children singing this song which was $u$ losha, a sign of respect in Vhavenda culture.

9. Malende is a traditional song and dance genre performed primarily by women and girls, typically one singer dances to drummers and improvises lyrics on a well-known melody.

\section{References}

Barbarin OA and Richter LM (2001) Mandela's Children: Growing up in Post-Apartheid South Africa. New York: Routledge.

Barron I (2014) Finding a voice: A figured worlds approach to theorising young children's identities. Journal of Early Childhood Research 12(3): 251-263.

Bennett A (2004) Popular Music and Youth Culture: Music, Identity and Place, 5th edn. Basingstoke: Macmillan.

Blacking J (1967) Venda Children's Songs. Johannesburg, South Africa: Witwatersrand University Press.

Blacking J (1990) Music in children's cognitive and affective development. In: Roehmann FL and Wilson FR (eds) Music and Child Development: Proceedings of the 1987 Denver Conference. St. Louis, MO: MMB Music, pp. 68-78.

Bradbury J and Clark J (2012) Echoes of the past in imaginings of the future: The problems and possibilities of working with young people in contemporary South Africa. Global Studies of Childhood 2(3): 176-189.

Bray R (ed.) (2010) Growing up in the New South Africa: Childhood and Adolescence in PostApartheid Cape Town. Cape Town, South Africa: HSRC Press. 
Bucknall S (2012) Children as Researchers in Primary Schools: Choice, Voice, and Participation. London: Routledge.

Campbell PS (2010) Songs in Their Heads: Music and Its Meaning in Children's Lives, 2nd edn. New York: Oxford University Press.

Campbell PS and Wiggins T (eds) (2013) The Oxford Handbook of Children's Musical Cultures. New York: Oxford University Press.

Carmel S and Greene S (2014) Key Thinkers in Childhood Studies. Bristol: Policy Press.

Cronje F, Kane-Berman J, Dimant T, et al. (eds) (2015) Born free but still in chains: South Africa's first post-apartheid generation. Report, South African Institute of Race Relations, Johannesburg, South Africa. Available at: http://irr.org.za/reports-and-publications/occasional-reports/files/irr-report-2013-born-free-but-still-in-chains-april-2015.pdf.

Emberly A (2009) Mandela went to China ... and India too: Musical cultures of childhood in South Africa. University of Washington, Washington, DC, ProQuest UMI.

Emberly A (2013) Venda children's musical cultures in Limpopo, South Africa. In: Wiggins T and Campbell P (eds) Oxford Handbook of Children's Musical Cultures. Oxford: Oxford University Press, pp. 77-95.

Emberly A and Davhula MJ (eds) (2014) Looking Back, Looking Forward: Vhavenda Musical Life as Documented by John Blacking 1956-1958. Grahamstown, South Africa: International Library of African Music.

Emberly A and Davhula MJ (2015) "Proud of Who I Am": Venda children's musical cultures. Smithsonian Folkways Magazine, Spring 2014. Available at: http://www.folkways.si.edu/ magazine-spring-2014-proud-of-who-i-am-venda-childrens-musical-cultures/south-africa/ music/article/smithsonian.

Emberly A and Davidson J (2011) From the Kraal to the classroom: Shifting musical arts practices from the community to the school with special reference to learning Tshigombela in Limpopo, South Africa. International Journal of Music Education 29(3): 265-281.

Green L (2011) Learning, Teaching and Musical Identity: Voices across Culture. Bloomington, IN: Indiana University Press.

Grover S (2004) Why won't they listen to us? On giving power and voice to children participating in social research. Childhood 11(1): 81-93.

Hallett C and Prout A (eds) (2003) Hearing the Voices of Children: Social Policy for a New Century. London: Routledge.

Herbst A, Nzewi M and Agawu K (eds) (2003) Musical Arts in Africa: Theory, Practice and Education. Pretoria, South Africa: University of South Africa (UNISA) Press.

Hill M (2006) Children's voices on ways of having a voice: Children's and young people's perspectives on methods used in research and consultation. Childhood 13(1): 69-89.

Hohti R and Karlsson L (2014) Lollipop stories: Listening to children's voices in the classroom and narrative ethnographical research. Childhood 21(4): 548-562.

Huq R (2006) Beyond Subculture: Pop, Youth and Identity in a Postcolonial World. London; New York: Routledge.

I'anson J (2013) Beyond the child's voice: Towards an ethics for children's participation rights. Global Studies of Childhood 3(2): 104-114.

Jackson AY and Mazzei LA (eds) (2009) Voice in Qualitative Inquiry: Challenging Conventional, Interpretive, and Critical Conceptions in Qualitative Research. London; New York: Routledge.

Jackson M (ed.) (1996) Things as They Are: New Directions in Phenomenological Anthropology. Bloomington, IN: Indiana University Press.

James A (2007) Giving voice to children's voices: Practices and problems, pitfalls and potentials. American Anthropologist 109(2): 261-272. 
Joubert I (2010) South Africa is my Best World: The Voices of Child Citizens in a Democratic South Africa. New York: Peter Lang.

Joubert I, Ebersöhn L and Eloff I (2010) How post-apartheid children express their identity as citizens. Childhood 17(3): 396-410.

Komulainen S (2007) The ambiguity of the child's "Voice" in social research. Childhood 14(1): $11-28$.

Kruger J (2014) The Girls in the Baobab Tree: Venda Stories from the Limpopo Valley. Potchefstroom, South Africa: Musical Arts in South Africa-Resources and Applications.

Lewis A (2010) Silence in the context of "Child Voice." Children and Society 24(1): 14-23.

Lundy L (2007) "Voice" is not enough: Conceptualising article 12 of the United Nations convention on the rights of the child. British Educational Research Journal 33(6): 927-942.

McTavish M, Streelasky J and Coles L (2012) Listening to children's voices: Children as participants in research. International Journal of Early Childhood 44(3): 249-267.

Marsh K (2008) The Musical Playground: Global Tradition and Change in Children's Songs and Games. New York; Oxford: Oxford University Press.

Mattes R (2012) The "Born Frees": The prospects for generational change in post-apartheid South Africa. Australian Journal of Political Science 47(1): 133-153.

Minks A (2002) From children's song to expressive practices: Old and new directions in the ethnomusicological study of children. Ethnomusicology 46(3): 379-408.

Mokoena HA (2014) Youth: "Born Frees" and the predicament of being young in post-apartheid South Africa. Ufahamu: A Journal of African Studies 38(1): 119-136.

Newman KS and Lannoy AD (2014) After Freedom: The Rise of the Post-Apartheid Generation in Democratic South Africa. Boston, MA: Beacon Press.

Phillips D (1995) Giving voice to young children. European Early Childhood Education Research Journal 3(2): 5-14.

Ridge T (2005) Hearing the voices of children. Journal of Social Policy 34(2): 334-336.

Schnoor O (2012) Early childhood studies as vocal studies: Examining the social practices of "Giving Voice to Children's Voices" in a Crèche. Childhood 20(4): 458-471.

Serpell R and Marfo K (2014) Some growth points in African child development research. In: Serpell R and Marfo K (eds) Child Development in Africa: Views from Inside: New Directions for Child and Adolescent Development, vol. 146. Hoboken, NJ: John Wiley \& Sons, pp. 97-112.

Spyrou S (2011) The limits of children's voices: From authenticity to critical, reflexive representation. Childhood 18(2): 151-165.

Titon J (2015) Sustainability, resilience, and adaptive management for applied ethnomusicology. In: Pettan S and Titon J (eds) The Oxford Handbook of Applied Ethnomusicology. New York: Oxford University Press, pp. 157-198. 